\title{
Characterization of Pasteurized Milk Spoilage by Electronic Nose in Relation to its Selected Quality Parameters
}

\author{
Saleem Ehsan ${ }^{\mathrm{a}}$, Zahir Al-Attabi ${ }^{\mathrm{a}^{*}}$, Nasser Al-Habsi ${ }^{\mathrm{a}}$, Michel R. G. \\ Claereboudt $^{\mathrm{b}}$, and Mohammad Shafiur Rahman ${ }^{\mathrm{a}}$ \\ ${ }^{a}$ Department of Food Science and Nutrition \\ b Department of Marine Science and Fisheries, College of Agricultural and Marine Sciences, Sultan Qaboos \\ University, P. O. Box 34-123, Al-Khod 123, Oman \\ * Corresponding author \\ zaherr@squ.edu.om \\ TEL: +968-24143663
}

Received: 6 August 2020; Published online: 18 october 2021

\begin{abstract}
Pasteurized fresh milk requires an accurate estimation of shelf life under various conditions to minimize the risk of spoilage and product losses. Milk samples were stored for $56 \mathrm{~h}$ in an oven at $25{ }^{\circ} \mathrm{C}$ and for 15 days in a refrigerator at $4{ }^{\circ} \mathrm{C}$. Samples were analyzed using an electronic nose (e-nose), total bacterial count, titratable acidity and $\mathrm{pH}$ to determine the quality of milk. Principal Component Analysis (PCA) and Linear Discriminant Analysis (LDA) were used to analyze e-nose data of milk stored at $25{ }^{\circ} \mathrm{C}$, and $4{ }^{\circ} \mathrm{C}$. A clear shift in quality was identified by the e-nose, which also appeared in the total bacterial count after $24 \mathrm{~h}$ and 12 days for storage at 25 and $4{ }^{\circ} \mathrm{C}$, respectively. On the other hand, titratable acidity exceeded the normal limits of $0.14 \%-0.21 \%$ after $24 \mathrm{~h}$ for storage at $25{ }^{\circ} \mathrm{C}$ $(0.247 \pm 0.006 \%)$ and after 15 days for storage at $4{ }^{\circ} \mathrm{C}(0.25 \pm 0.01 \%)$. If $\mathrm{pH}$ was a good indicator of quality for samples stored at $25{ }^{\circ} \mathrm{C}$, it showed no clear trends for samples stored at $4{ }^{\circ} \mathrm{C}$. Based on the microbial count data and e-nose output, the milk had a shelf life of 0.3 day (i.e. $8 \mathrm{~h}$ ) when stored at $25{ }^{\circ} \mathrm{C}$. Shelf life was extended to 9 days when stored at $4{ }^{\circ} \mathrm{C}$.
\end{abstract}

Keywords: Pasteurized milk; Shelf-life; Spoilage; Electronic nose

\section{Introduction}

Beneficial bacteria are important in the production of fermented dairy products, while pathogens and spoilage bacteria have detrimental effects on milk quality and dairy products. The shelf life of pasteurized milk is around 14 days at chilled temperature and is affected by many factors, such as raw milk quality, production system, hygienic, and storage conditions (Bondoc, 2007). However, shelf life decreases with an increase in storage temperature. To determine the shelf life of pasteurized milk stored under different conditions, different quality indicators, such as microbial counts, titratable acidity (TA), $\mathrm{pH}$ and enzyme activity (i.e. lipase and protease) need to be performed (Ziyaina et al., 2018).

Food can be characterized by its aroma, which is related to the volatile organic compounds (VOCs). The mixture of VOCs represents the aroma characteristics of dairy products; therefore, consumers typically sniff milk to estimate its quality or freshness in the headspace of the milk container. The VOCs are thus a very important component of the sensory quality of processed and stored milk. Specific combinations of VOCs form a kind of fingerprint, which can be used as an indicator of food quality and safety. 
The VOCs in the headspace of milk were used to predict ageing and off-flavours development (Ali et al., 2003). The increase in the concentration of some aldehydes, ketones, alcohols, and esters during the storage of pasteurized milk indicates poor quality. Furthermore, Vallejocordoba and Nakai (1994a) found that the shelf life of pasteurized milk was better estimated by the analysis of the VOCs than by bacterial count.

Normally, the VOCs are qualitatively and quantitatively analyzed using gas chromatography (GC). Vallejocordoba and Nakai (1994a) successfully assessed the VOCs using dynamic headspace/GC to predict the shelf life of pasteurized milk. Recently, Rashid et al. (2019) found that acetone, butanone, pentanal, and ethanol were good indicators of spoilage of pasteurized milk during storage. This was done using headspace solid-phase micro-extraction (HS-SPME) coupled with a flame ionization detector (GCFID).

Different types of chemical sensors and commercial systems (e.g. electronic-nose and electronictongue) can also be used to detect milk spoilage. Recently, electronic noses (e-nose) have been successfully used to monitor microbial growth and shelf life of milk (Kalit et al., 2014). Using an array of five sensors, rancidity of ultra-heat treated (UHT) and pasteurized milk showed a good correlation with ageing of milk (Capone et al., 2001). In addition, a gas-sensing system was successfully used to distinguish between unspoiled milk and contaminated milk with selected bacteria or yeasts (Magan et al., 2001). The e-nose signals of sterile milk inoculated with Pseudomonas fluorescens or Bacillus coagulans were correlated with both the microbial loads and sensory scores of the milk (Korel \& Balaban, 2002). The e-nose has also been used to assess the bacterial growth and shelf life of milk when stored at $5{ }^{\circ} \mathrm{C}$ and at room temperature (i.e. 25 $\left.{ }^{\circ} \mathrm{C}\right)$ (Labreche et al., 2005).

There are limited studies on the use of e-nose for the shelf life determination of milk. In addition, in some countries, the milk may be subjected to high temperature (i.e. $45-50{ }^{\circ} \mathrm{C}$ ) during handling and storage. Therefore, predicting the exact shelf life of milk is necessary with varying temperatures of handling or storage (Ziyaina et al., 2018). It is also important to assure good qual- ity of milk for the production of other products, such as yoghurt and cheese. In both cases, fast quality assessment methods are needed for milk. Therefore, the aim of this study was to evaluate the application of the e-nose in monitoring pasteurized milk spoilage during storage at $25{ }^{\circ} \mathrm{C}$ and $4{ }^{\circ} \mathrm{C}$ in comparison to traditional means of quality estimates.

\section{Materials and Methods}

\subsection{Experimental Design}

Pasteurized milk (i.e. $500 \mathrm{~mL}$, Tetra Pak carton) spoilage was monitored using two storage temperatures, $25{ }^{\circ} \mathrm{C}$ and $4{ }^{\circ} \mathrm{C}$. The first set of pasteurized milk samples was stored at $25^{\circ} \mathrm{C}$ in a Labcon oven (LABOCON Corporation, USA) for $56 \mathrm{~h}$ (i.e. $0,8,12,24,32,41,48,56 \mathrm{~h}$ ) or 2.3 days $(0,0.3,0.5,1.0,1.3,1.7,2.0,2.3$ days $)$. The second set of pasteurized milk samples were stored at $4{ }^{\circ} \mathrm{C}$ in a refrigerator (Samsung, China) for 15 days and analyzed every three days (i.e. $0,3,6,9,15$ days). The milk samples were analyzed using the e-nose, microbial count, $\mathrm{pH}$, and TA. At the end of predetermined storage times, one milk carton was unsealed, and three sterile plastic containers were filled with $50 \mathrm{~mL}$ of milk to determine $\mathrm{pH}$, TA and microbial count (i.e. triplicate analysis). For e-nose analysis, five vials $(15 \mathrm{~mL})$ were filled with $5 \mathrm{~mL}$ milk. Controls were used before the start of the storage period.

\subsection{Materials}

Cartons of pasteurized milk (500 $\mathrm{mL}$ each) were collected from the College of Agricultural and Marine Sciences pilot dairy plant, Sultan Qaboos University, Oman. The high temperature short time pasteurization (HTST) was applied in the dairy plant $\left(72^{\circ} \mathrm{C}\right.$ for $\left.15 \mathrm{~s}\right)$. Milk samples were collected from the dairy plant after production and transferred to the Food Processing Laboratory on the day of production.

\subsection{E-nose Analysis}

A Cryanose 320 (Sensigent Company, California, USA), equipped with 32 sensors, was used in this 
study. Five $\mathrm{mL}$ of pasteurized milk sample was placed in a $15 \mathrm{~mL}$ glass vial (Supleco, Bellefonte, PA, USA) sealed with a rubber septum cap. Vials were kept at $4{ }^{\circ} \mathrm{C}$ until analysis. First, the e-nose sensors were calibrated with air and the e-nose parameters were optimized using similar procedures as Rahman et al. (2018): baseline purge (10 s), sample draw ( $5 \mathrm{~s})$, air intake purge $(20 \mathrm{~s})$, and sample purge (40 s). To measure the volatile profile of the stored milk headspace, the vial septum was punctured with a needle connected to the e-nose. This initiated the collection and transfer of the volatiles from the headspace to the sensors of the e-nose. Five replicates were done for each storage time.

\subsection{Optimization of Volatile Compounds Collection}

The optimization procedure included four predetermined times (5, 15, 30 and $50 \mathrm{~min})$ and three predetermined temperatures $(30,35$, and $40{ }^{\circ} \mathrm{C}$ ) of extraction. A water bath (Fisher Scientific (Cambridge) Ltd, England) was used to control the temperature of the vials during the extraction. The vials with milk samples took 5 and $3 \mathrm{~min}$ to reach the desired temperature from their storage temperature, i.e. 4 and $25{ }^{\circ} \mathrm{C}$, respectively. The milk sample stored at $4{ }^{\circ} \mathrm{C}$ was considered as a standard. The experiment was replicated ten times, with each vial considered as a single replicate.

\section{$2.5 \mathrm{pH}$ measurement and Titratable Acidity}

Measurements of the milk $\mathrm{pH}$ were taken using $\mathrm{pH} / \mathrm{Mv} /{ }^{\circ} \mathrm{C}$ meter from EUTECH Instruments, Singapore. The TA analysis was performed in triplicate. Approximately $50 \mathrm{~g}$ of stored milk samples in glass bottles were used for TA analysis. The milk sample $(9 \mathrm{~g})$ was placed in a conical flask and three drops of phenolphthalein solution $(1 \%)$ were then added. It was then titrated using $0.1 \mathrm{~N} \mathrm{NaOH}$ (SigmaAldrich, Switzerland) until a pink colour appeared. The titration volume (i.e. V) of $\mathrm{NaOH}$ was recorded and TA was then calculated (Wehr et al., 2004) according to the following formula.

$$
\% \text { acidity }=\frac{N(\mathrm{NaOH}) \times \mathrm{V}(\mathrm{NaOH}) \times(0.09)}{\text { Sample weight }} \times 100
$$

\subsection{Microbial Count}

Milk samples were placed in sterilized plastic containers and transported immediately to the laboratory for measuring the total plate count. The procedures were performed according to Wehr et al. (2004). Peptone maximum recovery diluent was used. Under sterile conditions, several dilutions of milk samples were prepared, and triplicate dishes were prepared for every dilution. The Petri dishes were placed in the incubator (BINDER, Germany) at $32{ }^{\circ} \mathrm{C}$ for $48 \mathrm{~h}$. After $48 \mathrm{~h}$, total bacterial colonies were counted using a colony counter (Gallenkamp Co. Ltd., England).

\section{7 $\quad$ Statistical Analysis}

E-nose data were analyzed using Principal Component Analysis (PCA) (Past Software version 2.17 c) (Hammer et al., 2001) and Linear Discriminant Analyses (LDA) with R package (RStudio, 2019). The microbial count and TA were assessed using ANOVA followed by Tukey's posthoc test $(\alpha=0.05)$ for mean separation in $\mathrm{R}$. In order to determine the optimal volatile release conditions, a non-metric Multidimensional Scaling (MDS) was used.

\section{Results and Discussion}

\subsection{Total Bacterial Count and Acidity}

Total Bacterial Count (TBC) (expressed as $\log _{10}$ $\mathrm{cfu} \mathrm{mL}^{-1}$ ) showed no significant change until $8 \mathrm{~h}$ $(0.3 \mathrm{~d})$ of storage at $25{ }^{\circ} \mathrm{C}$ when total microbial count was $2.42 \pm 0.20 \log _{10} \mathrm{cfu} \mathrm{mL}^{-1}$ (Fig. 1A) ( $p<0.05$, Tukey's test). This initial low microbial count was below the acceptable limit of pasteurized milk of $4.3 \log _{10} \mathrm{cfu} \mathrm{mL}^{-1}$ (Food and Drug Administration, 2017). A significant increase in the TBC $\left(7.7 \pm 0.07 \log _{10} \mathrm{cfu} \mathrm{mL}^{-1}\right)$ 
was observed after $24 \mathrm{~h}$, which then exceeded the spoilage limit of $5 \log 10 \mathrm{cfu} \mathrm{mL}^{-1}(p<0.05)$ (Ziyaina et al., 2019). Similar values of TBC for pasteurized milk stored at ambient temperature after $24 \mathrm{~h}$ of storage was observed as $8.18 \log _{10}$ cfu $\mathrm{mL}^{-1}$ (Labreche et al., 2005). The shelf life of the pasteurized milk used in this study was shown to be approximately $8 \mathrm{~h}$ (i.e. $0.3 \mathrm{~d}$ ) at $25{ }^{\circ} \mathrm{C}$, which was similar to the results of Lucknakhul et al. (2014) (i.e. $0.35 \mathrm{~d}$ at the $25^{\circ} \mathrm{C}$ ). In contrast, pasteurized milk stored at 19, 15 and 13 ${ }^{\circ} \mathrm{C}$ had an increased shelf life of $24 \mathrm{~h}(1 \mathrm{~d}), 36$ (1.5 d) and $72 \mathrm{~h}$ (3 days) respectively when the microbial count exceeded the spoilage limit of $5 \log _{10}$ cfu $\mathrm{mL}^{-1}$ (Ziyaina et al., 2019). Considering the Gompertz model for microbial growth curves, the lag periods $\left(t_{L}\right)$ of the current study were 6.0 and 0.3 day (s) for storage temperatures 4 and 25 ${ }^{\circ} \mathrm{C}$, respectably, while maximum growths $\left(\mu_{\max }\right)$ were 0.6 and $12.4\left(\log _{10} \mathrm{cfu} \mathrm{mL}^{-1} 1\right)$ day, respectively.

The TA increased exponentially as a function of storage time $\left(\mathrm{R}^{2}\right.$ : 0.971) (Fig. $\left.1 \mathrm{~B}\right)$ and reached $0.25 \pm 0.01 \%$ after $24 \mathrm{~h}$. Similarly, Ziyaina et al. (2018) noticed an increase $(<0.20 \%)$ in TA (above $5 \log _{10} \mathrm{cfu} \mathrm{mL}^{-1}$ of TBC) after $24 \mathrm{~h}$ of storage at $19{ }^{\circ} \mathrm{C}$. On the other hand, the $\mathrm{pH}$ decreased linearly during storage (Fig. 1B) and after $24 \mathrm{~h}$, decreased to 6.43 , below the normal $\mathrm{pH}$ range of milk (6.6-6.8). Similar findings were reported by Lucknakhul et al. (2014) at $25{ }^{\circ} \mathrm{C}$. On the other hand, after $24 \mathrm{~h}$ the TA increased (i.e. $0.34 \pm 0.0 \%-0.53 \pm 0.02 \%$ ) above the normal range 0.14 to $0.21 \%$ (Walstra et al., 2005). A similar result was also observed by Lucknakhul et al. (2014). The sourness of pasteurized milk stored at ambient temperature was attributed to either the activity of mesophilic microorganisms, which normally survive pasteurization. Alternatively, the putrefaction of pasteurized milk could cause sourness due to the presence of psychrotrophic bacteria (such as Pseudomonas species), which may be the result of a re-contamination after pasteurization (Al-Qadiri et al., 2008).

There were no significant changes in TBC for the milk stored at $4{ }^{\circ} \mathrm{C}$ until the sixth day (i.e. 2.48 $\pm 0.04 \log _{10} \mathrm{cfu} \mathrm{mL}^{-1}$ ) of cold storage (Fig. 2A). Then TBC increased significantly in the ninth day $\left(4.89 \pm 0.21 \log _{10} \mathrm{cfu} \mathrm{mL}^{-1}\right)$ exceeding the permitted limit of grade A pasteurized milk (i.e.
$4.3 \log _{10} \mathrm{cfu} \mathrm{mL} \mathrm{mL}^{-1}$ ) (Food and Drug Administration, 2017). However, spoilage onset is typically considered when the bacterial count exceeds $5.0 \log _{10} \mathrm{cfu} \mathrm{mL} \mathrm{mL}^{-1}$ (Ziyaina et al., 2018). Others reported that the milk reached the end of its shelf life when the total bacterial counts reached values of 6.0-7.0 $\log _{10} \mathrm{cfu} \mathrm{mL}^{-1}$ (Harding, 1995; McAuley et al., 2016). Our milk had a bacteriological shelf life of approximately 9 days at 4 ${ }^{\circ} \mathrm{C}$. In contrast, the shelf life of pasteurized milk stored at $6{ }^{\circ} \mathrm{C}$ was 4 days as observed by Lucknakhul et al. (2014).

Recently, Rashid et al. (2019) studied the shelf life of pasteurized milk at different temperatures (e.g. 4 and $7{ }^{\circ} \mathrm{C}$ ) for 19 days. The bacterial count after 9 days of storage at 4 and $7{ }^{\circ} \mathrm{C}$ were 3.27 and $3.64 \log _{10} \mathrm{cfu} \mathrm{mL}^{-1}$, respectively. Furthermore, the bacterial count increased to 3.72 , 4.41 , and $5.46 \log _{10} \mathrm{cfu} \mathrm{mL}^{-1}$ at $4{ }^{\circ} \mathrm{C}$ after storage for 12,14 , and 16 days, respectively. Another study by Labreche et al. (2005) showed that pasteurized milk stored at $5{ }^{\circ} \mathrm{C}$ for 9.2 days reached TPC of $7.1 \log _{10} \mathrm{cfu} \mathrm{mL}^{-1}$. Their finding is higher than our measured microbial count after 9 days of storage (i.e. $4.89 \pm 0.21 \log _{10} \mathrm{cfu}$ $\mathrm{mL}^{-1}$ at $\left.4^{\circ} \mathrm{C}\right)$. The variations of the reported results may be due to the varied sources of milk, processing conditions, and post-handling of pasteurized milk and the different temperature conditions. In addition, microbial count, heat stable enzymes (i.e. lipase and protease produced by psychotropic bacteria) of raw milk, and the activity of native plasmin and lipoprotein could play a role in determining the shelf life of milk.

The $\mathrm{pH}$ and $\mathrm{TA}$ values of milk stored at $4{ }^{\circ} \mathrm{C}$ are presented in the Figure $2 \mathrm{~B}$. The $\mathrm{pH}$ values showed no significant changes until it reached 6.70 at the end of day 15. It was within the normal pH range of fresh milk 6.6-6.8 (Walstra et al., 2005). Similarly, at $5{ }^{\circ} \mathrm{C}$ storage, the change of the $\mathrm{pH}$ value was within the acceptable range at 16 (Ziyaina et al., 2018) and 14 days (Sadhu, 2018). At higher storage temperatures, such as 13,15 , and $19{ }^{\circ} \mathrm{C}$, the $\mathrm{pH}$ reached at 6.5 within 3,2 , and 1 day(s) storage, respectively (Ziyaina et al., 2018).

The TA is a better indicator of shelf life of pasteurized milk compared to $\mathrm{pH}$ (Ziyaina et al., 2018). The current study showed insignificant changes in the TA (Figure 2B) until day 9 (i.e. 
from $0.160 \pm 0.01$ to $0.177 \pm 0.11 \%$ ). This finding is within the acceptable range of TA (i.e. 0.14 to $0.21 \%$ ) of fresh milk (Walstra et al., 2005). Similarly, Slewa and Azhar (2018) reported 0.16 $\%$ and $0.17 \%$ TA after 1 and 3 days of storage at $6{ }^{\circ} \mathrm{C}$. However, a significant increase in TA to 0.18 and $0.25 \%$, was observed in the current study after 12 and 15 days, respectively and this trend was similar to the bacterial counts. The sharp increase in acidity after 12 days was likely due to the fermentation process of lactose to lactic acid.

\subsection{Optimization of VOCs Headspace Collection}

The optimum conditions of volatiles released in the headspace are illustrated in Figure 3. All increased duration and increased temperatures of extraction enhanced the response of all sensors compared to the standard. The standard response was considered as the pasteurized milk stored at $4{ }^{\circ} \mathrm{C}$. Each plot shows the effect of storage time with extraction at $30{ }^{\circ} \mathrm{C}$ (Fig. 3A), $35{ }^{\circ} \mathrm{C}$ (Fig. 3B) and $40{ }^{\circ} \mathrm{C}$ (Fig. 3C), respectively. The overall responses of the sensors increased with time, and $30 \mathrm{~min}$ at $40{ }^{\circ} \mathrm{C}$ showed the highest responses (i.e. optimum) (Fig. 3C and Fig. 4), but longer volatile release time (i.e. 40 and $50 \mathrm{~min}$ ) at $40{ }^{\circ} \mathrm{C}$ did not show any further increase in the response (Fig. 3C). Therefore, $30 \mathrm{~min}$ and $40{ }^{\circ} \mathrm{C}$ were considered as the optimal conditions for volatile release. Published research shows that temperatures of $20-50{ }^{\circ} \mathrm{C}$ and times of 3-90 min were usually used for volatile release. For example, Oliveros et al. (2005) used $40{ }^{\circ} \mathrm{C}$ for $30 \mathrm{~min}$ in order to create a homogeneous headspace, and they mentioned that $38-40{ }^{\circ} \mathrm{C}$ allowed for easier comparisons. In this study, temperatures higher than $40{ }^{\circ} \mathrm{C}$ were not used due to the possibility of generating new volatiles as a result of overheating. VazquezLandaverde et al. (2005) also pointed out that higher temperatures $\left(45^{\circ} \mathrm{C}\right.$ to $\left.75{ }^{\circ} \mathrm{C}\right)$ could lead to generating new volatiles in milk as an effect of heating.

The response of the sensors was also analyzed by non-metric Multidimensional Scaling (MDS) (using a Euclidean distance) to quantify the op- timum conditions. If we consider as optimal the largest possible distance in the nose-response space, the optimum is reached when the distance is the largest on the MDS plot, which was $40{ }^{\circ} \mathrm{C}$ and $30 \mathrm{~min}$ (Fig. 5). The high distances, from the standard (marked as S) in the MDS biplot, indicates high response. Similarly, Groenen and Borg (2015) used MDS to visualize the optimum conditions (i.e. time and temperature) of volatile release.

\section{$3.3 \quad$ E-nose Output of Fresh Pasteurized Milk Stored at 25 ${ }^{o} \mathrm{C}$}

The 6 days of measurements (i.e. $0,0.3,1,1.3,2$, and 2.3) formed 6 natural clusters, marked A-F on the PCA coordinate plot (Fig. 6). The visual clusters B, C, D, E, and F shifted to the left compared to the initial storage (i.e. cluster A). The cluster B for 0.3 day showed only a marginal shift from cluster A, while other clusters (i.e. C, D, E, and F) showed considerable shifts. This change in position in the PCA plot could be correlated with the significant increase in the microbial count observed in the samples corresponding to the additional storage duration, which may have led to the formation of additional volatiles. The e-nose response of cluster D shifted down compared to cluster $\mathrm{C}$ followed by further lift up (i.e. clusters $\mathrm{E}$ and F). There was a minimal change in microbial count between clusters C, D, and E compared to cluster F. Similarly, using PCA, Capone et al. (2001) identified three classes of milk as rancidity increased during storage. They also observed that the classes of milk shifted to the left as rancidity occurred. Similarly, in the case of fish fillet storage, Di Natale et al. (2001) was unable to classify samples within 1 and 7 days, while at day 11 a clear separation of the samples was observed on the PCA plots.

\subsection{E-Nose Output of Pasteurized Milk Stored at $4{ }^{\circ} \mathrm{C}$}

On the PCA plot (Fig. 7), two distinct groups of points emerged (A and B). There were no particular trends in the location of all the data points 

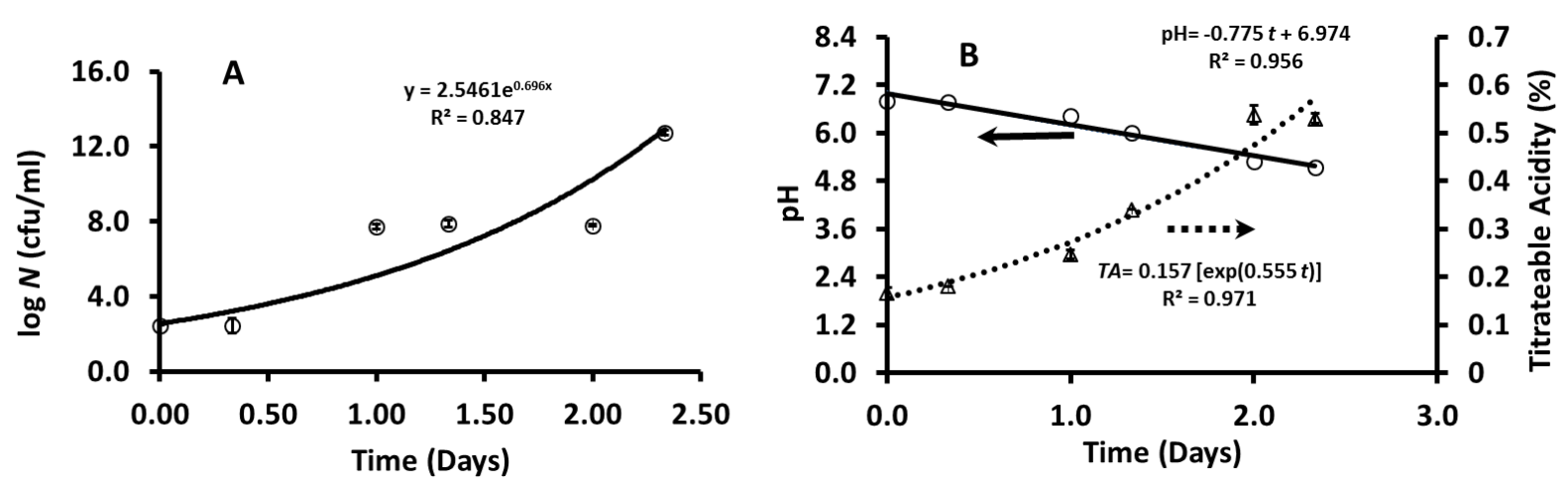

Figure 1: Total Bacterial Count (A) Titratable acidity and $\mathrm{pH}(\mathrm{B})$ of fresh pasteurized milk stored at $25^{\circ} \mathrm{C}$ for 56 hours (2.3 days). (Data are plotted as means $\left.\pm 2 \mathrm{SD}\right)$.
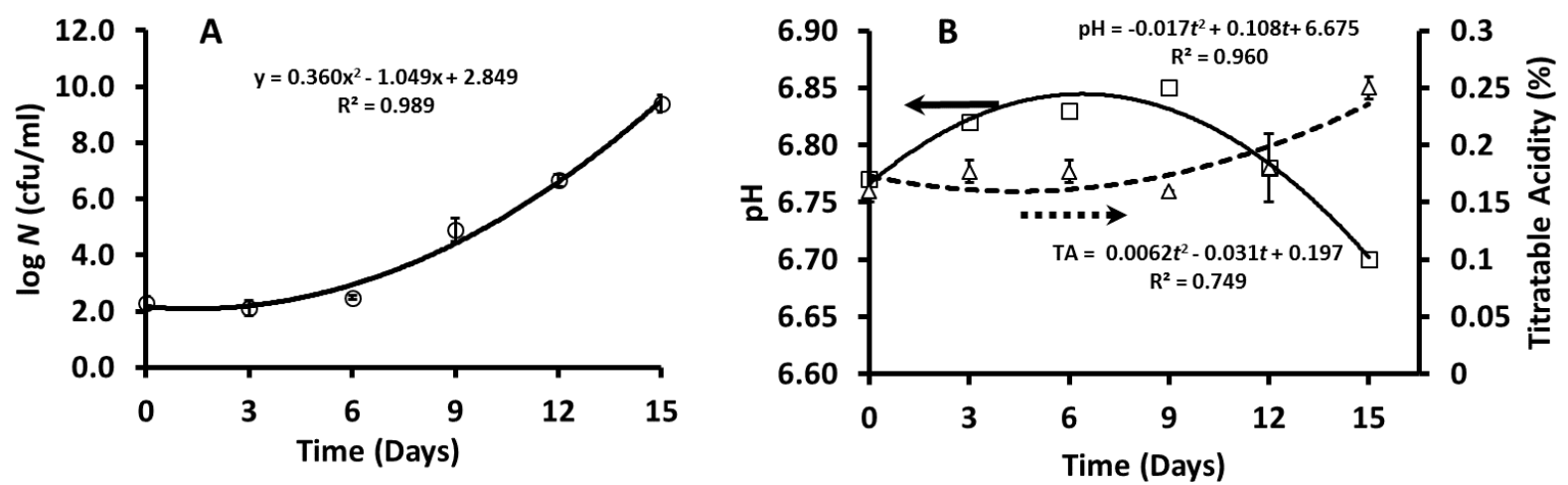

Figure 2: Total Bacterial Count (A) Titratable acidity and pH (B) of fresh pasteurized milk stored at 4 ${ }^{\circ} \mathrm{C}$ for 15 days. (Data are plotted as means $\pm 2 \mathrm{SD}$ ).

after $0,3,6,9$, and 12 days of storage but there was a large jump after 15 days (Fig. 7). A linear discriminant analysis (LDA) was applied to analyze the e-nose data (i.e. multiple regression of day as a function of 32 sensors' signals). Four discriminant functions (LD1, LD2, LD3, and LD4) were obtained, which described variances as $72.96,14.79,7.11$, and $1.78 \%$ respectively. Based on the values of the coefficients, sensors 5, 18, 1, 31, 25, 23, and 20 showed high contribution to separate the clusters (i.e. highest responses to VOCs responsible for spoilage). Figure 8 shows the bar plot of the first discriminate scores as a function of storage days. Samples on day 0 , day 3 , and day 6 had a negative contribu- tion to the discriminate function (DF) (i.e. there was negligible response of spoilage sensors). In contrast, samples at day 12 and day 15 had a positive contribution to the DF (i.e. major spoilage occurred). On day 9, the responses contributed to the discriminate function both positively and negatively; and this could be considered perhaps a transition phase of the major volatiles (Fig. 8). On the biplot of LDA as a function of LD1 and LD2 (Fig. 9), six clusters (i.e. A, B, C, D, E, and $\mathrm{F}$ ) were identified each representing different storage days (i.e. $0,3,6,9,12$, and 15 days, respectively). Clusters A, B, C, and D were clearly separated from the clusters $\mathrm{E}$ and F (i.e. moved from left to right). The clusters E 
Characterizing pasteurized milk by e-nose $\mid 389$
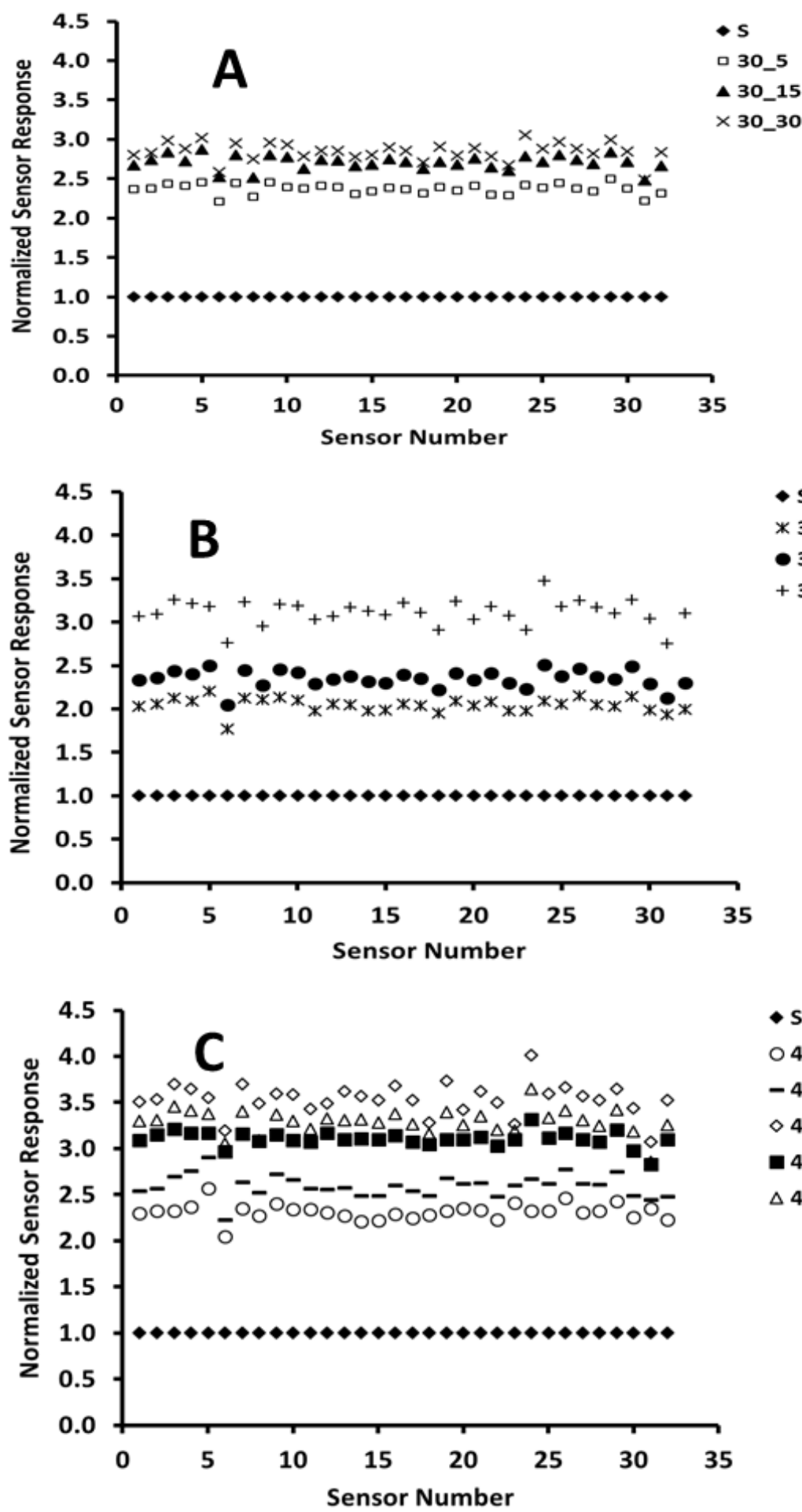

- 5

* 35_5

- 35_15

+ 35_30

\section{- 5}

0 40_5

-40_15

$\checkmark 40 \_30$

- 40_40

$\triangle 40 \_50$

Figure 3: Normal analysis of e-nose signals of milk heated for specific times at specific temperatures: (A) $30{ }^{\circ} \mathrm{C},(\mathrm{B}) 35{ }^{\circ} \mathrm{C}$ and $(\mathrm{C}) 40{ }^{\circ} \mathrm{C}$. 


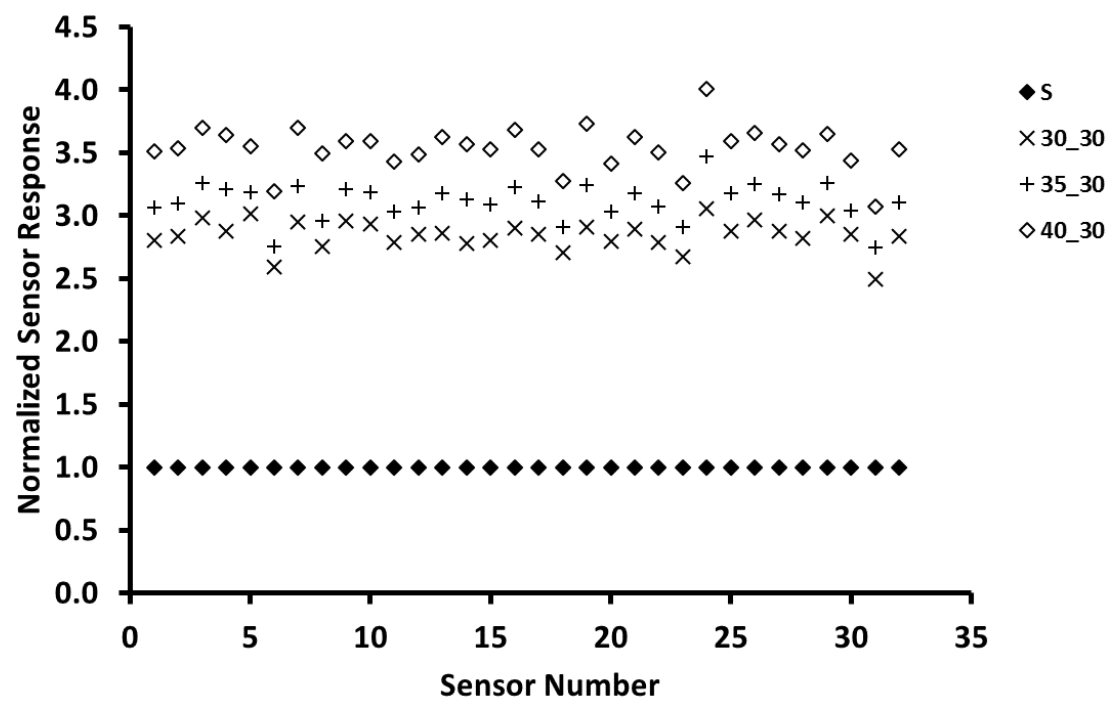

Figure 4: Normal analysis of e-nose signals of milk heated for $30 \mathrm{~min}$ at specific temperatures.

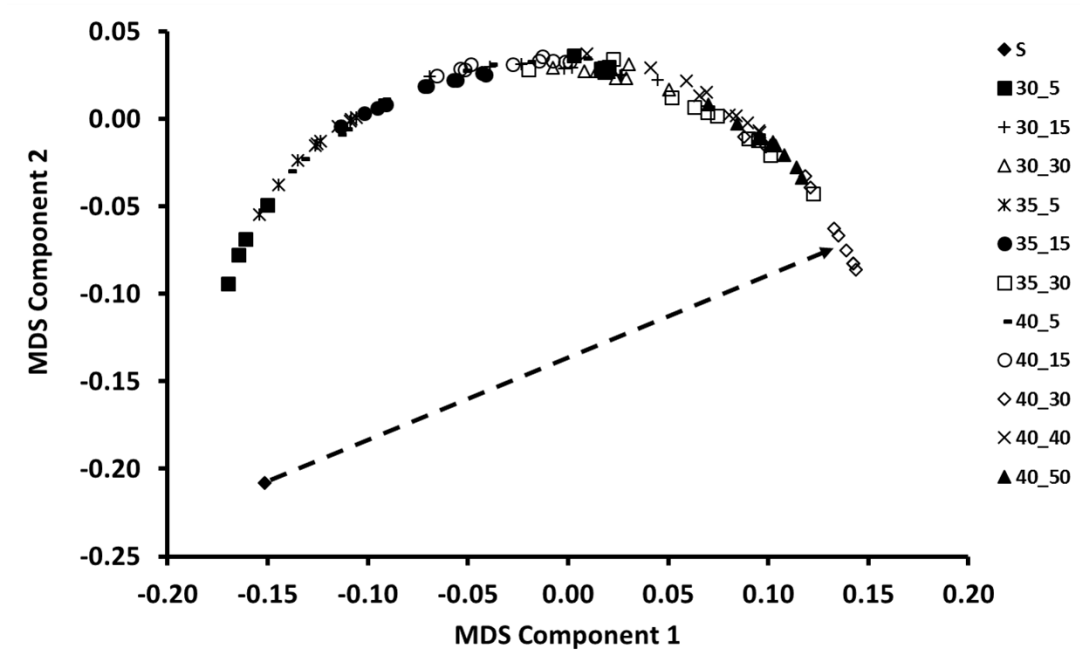

Figure 5: Biplot of MDS (Euclidean) analysis of e-nose signals of milk heated for specific times at specific temperatures (Arrow shows the distance between the reference and optimum measurement condition). 
Characterizing pasteurized milk by e-nose $\mid 391$

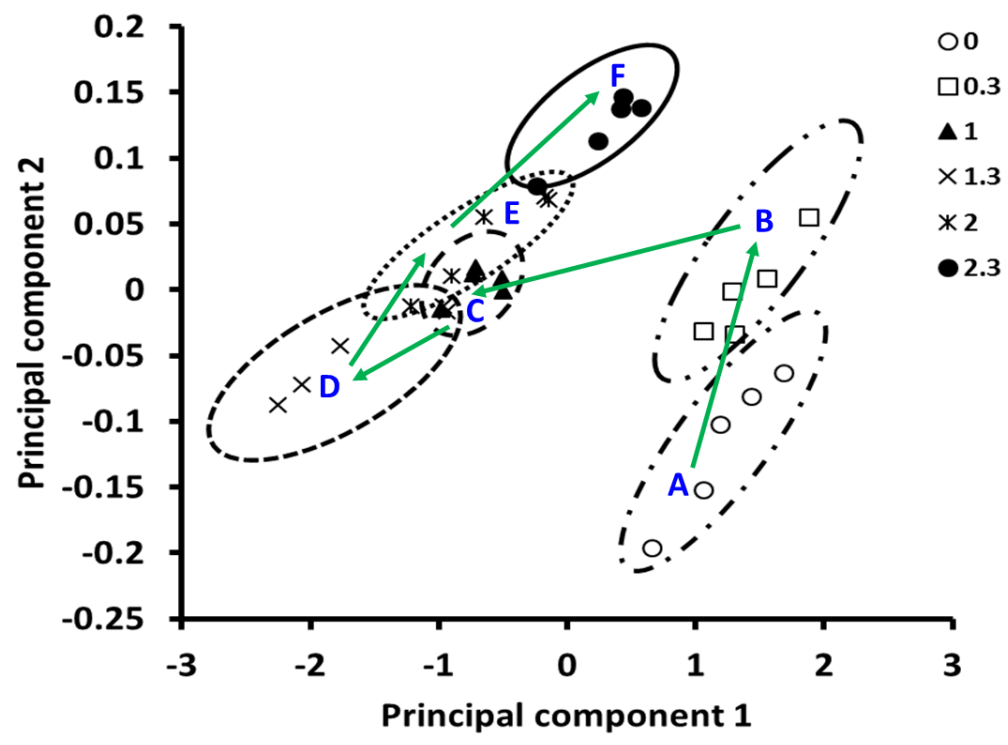

Figure 6: Plot of 2 first principal components of the e-nose signals of milk stored at $25^{\circ} \mathrm{C}$ as a function of time (56 hours or 2.3 days of storage) (Circles show the groupings).

and $\mathrm{F}$ showed an onset shift from day 9, which could be related to the beginning of changes in the volatile profile of milk. The same transition was also observed when the microbial count indicated the onset of spoilage. Thereafter, a clear and considerable shift of clusters to the right side of the biplot was observed for samples collected on days 12 and 15 . This shift was related to the significant increase in the bacterial count, which was likely due to the formation of new volatile compounds. Rashid et al. (2019) detected six compounds in fresh pasteurized milk stored at 4 ${ }^{\circ} \mathrm{C}$ (i.e. 2 ketones, 2 alcohols, and 2 aldehydes). The numbers of compounds increased to 12 (3 ketones, 7 alcohols, and 2 aldehydes) at the end of a 19 days storage period. In the present study, a significant change in volatiles was observed on day 12 instead of day 19. This variation between the current study and the literature data presented above could be due to the initial microbial contamination (types and microbial counts) in the fresh milk.

It was clearly observed that LDA was a better classifier compared to the PCA. This was due to the linear assumption of PCA which is not designed to separate groups. It is only designed to show the directions of maximum variability along with a series of the independent axis (i.e. it removes the correlations between variables). However, LDA is a linear classifier and calculates the best linear combination of variables in separating the known groups. Therefore, LDA has the ability to handle complex linear responses of e-nose signals. In addition, it improves the discrimination by maximizing the separation between the groups while minimizing the variance within the groups and within the inter-groups (Tohidi et al., 2018). Furthermore, the LDA was successfully used to predict the shelf life of pasteurized milk (Vallejocordoba \& Nakai, 1994b).

\subsection{Quality Grade Assessment of Pasteurized Milk}

The e-nose could also be used to classify different quality grades of milk in addition to the discriminating milk during storage periods. In this study, three grades of pasteurized milk (i.e. stored at $4{ }^{\circ} \mathrm{C}$ ) were proposed based on the volatiles measured by the e-nose and the bacterial count (Table 1 and Fig. 10): excellent, good, 
$392 \mid$ Ehsan et al.

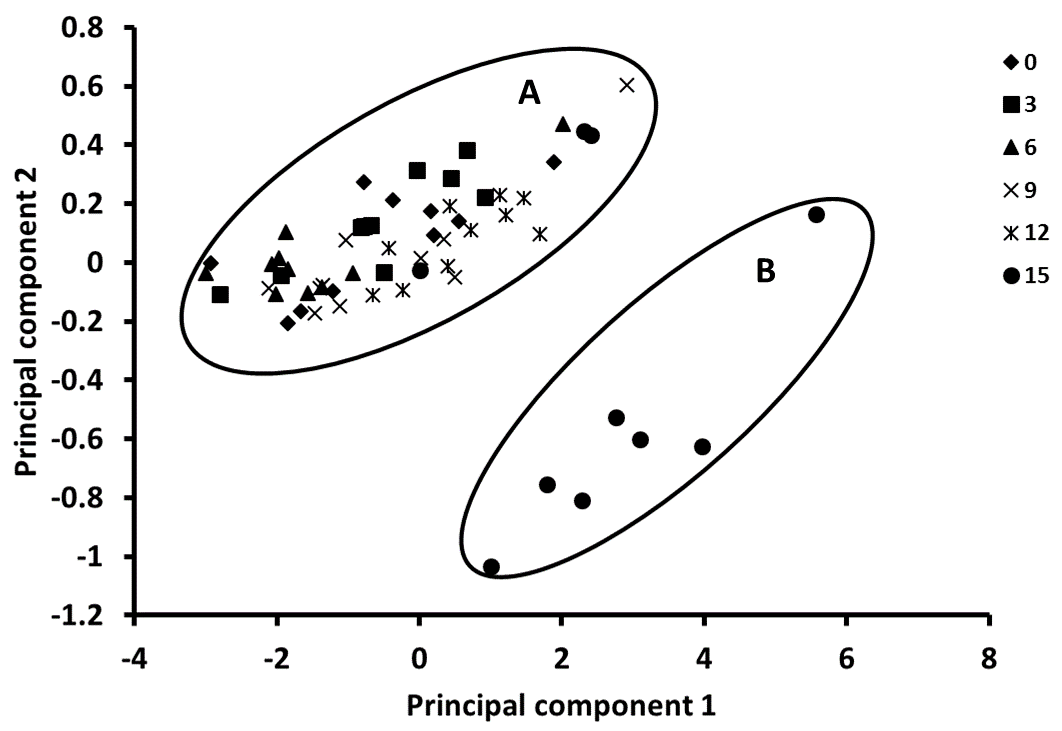

Figure 7: Biplot of principal components analysis of e-nose signals of milk stored at $4{ }^{\circ} \mathrm{C}$ as a function of time (15 days of storage). (Circles show the groupings).

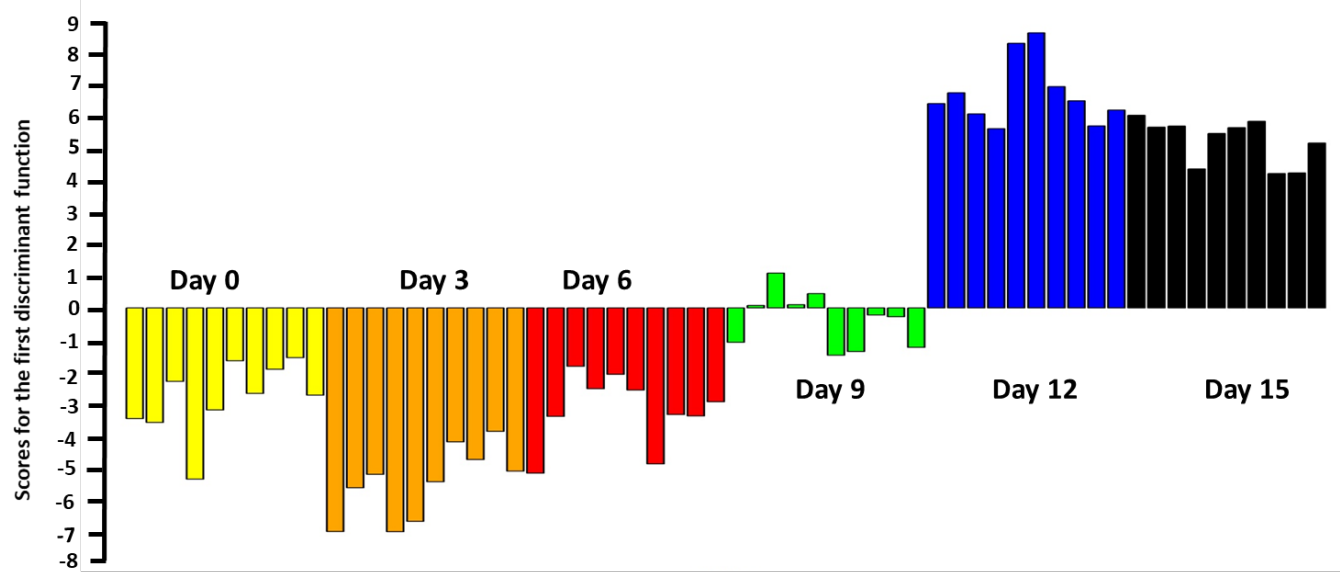

Figure 8: First discriminant scores (LD1) as a function of time (days). 


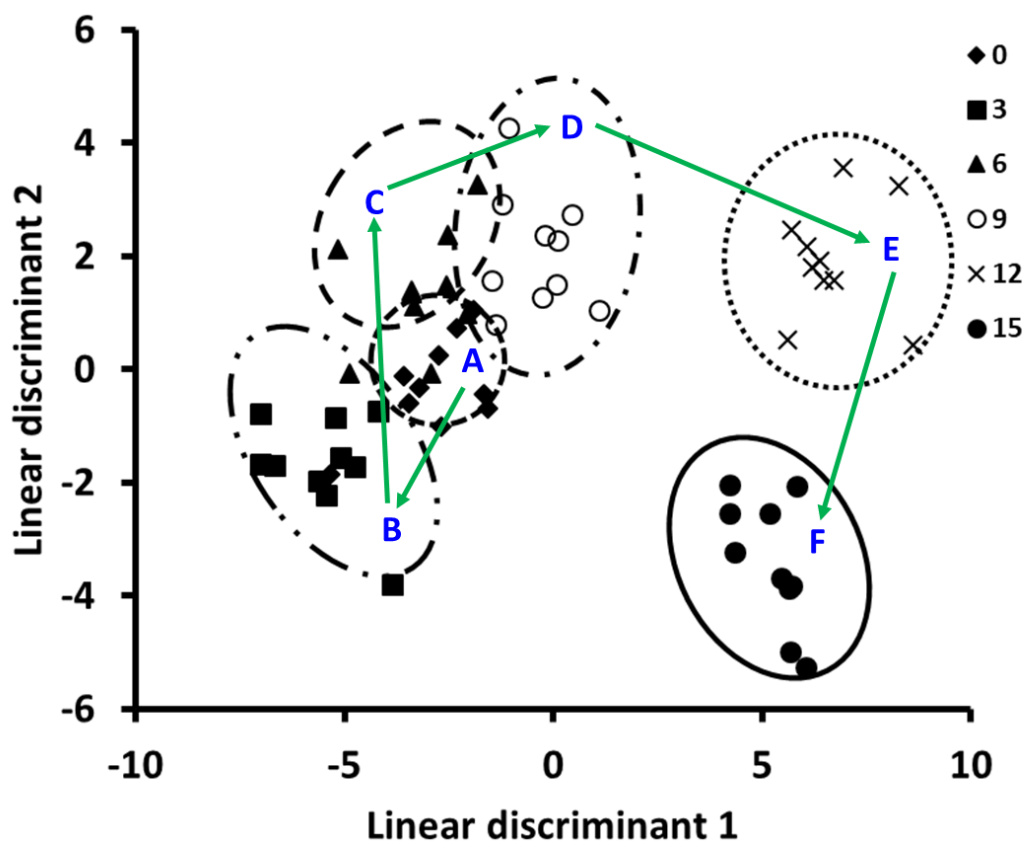

Figure 9: Biplot of Linear Discriminant Analysis of e-nose signals of fresh pasteurized milk stored at 4 ${ }^{\circ} \mathrm{C}$ as a function of time (15 days). (Circles show the groupings).

Table 1: Quality classes of pasteurized milk during common storage $\left(4^{\circ} \mathrm{C}\right)$.

\begin{tabular}{lcc}
\hline Quality Class & $\begin{array}{c}\text { Storage } \\
(\text { days })\end{array}$ & $\begin{array}{c}\text { Total Bacterial Count } \\
\left(\log _{10} \mathrm{cfu} \mathrm{mL}^{-1}\right)\end{array}$ \\
\hline Excellent & $0-6$ & $\leq 2.48 \pm 0.04$ \\
Good & 9 & $4.89 \pm 0.21$ \\
Poor & $12-15$ & $\geq * 5.00$ \\
\hline * Spoilage onset &
\end{tabular}

Table 2: Quality classes of pasteurized milk during room temperature storage $\left(25^{\circ} \mathrm{C}\right)$

\begin{tabular}{lcc}
\hline Quality Class & $\begin{array}{c}\text { Storage } \\
(\text { days })\end{array}$ & $\begin{array}{c}\text { Total Bacterial Count } \\
\left(\log _{10} \mathrm{cfu} \mathrm{mL} \mathrm{m}^{-1}\right)\end{array}$ \\
\hline Non-spoiled & $0-0.3$ & $\leq 2.42 \pm 0.20$ \\
Spoiled & $1-2.3$ & $\geq{ }^{*} 5.00$ \\
\hline * Spoilage onset & &
\end{tabular}


394 Ehsan et al.

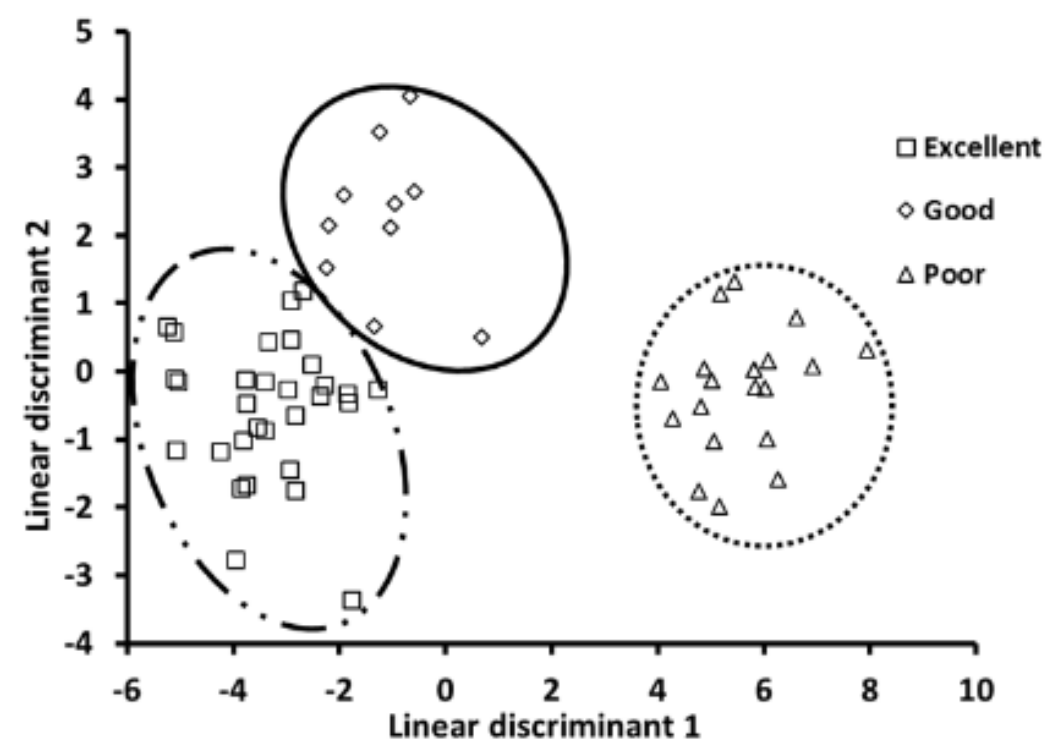

Figure 10: Quality classes of fresh pasteurized milk stored at $4{ }^{\circ} \mathrm{C}$ as a function of time (15 days) (Circle show the groupings).

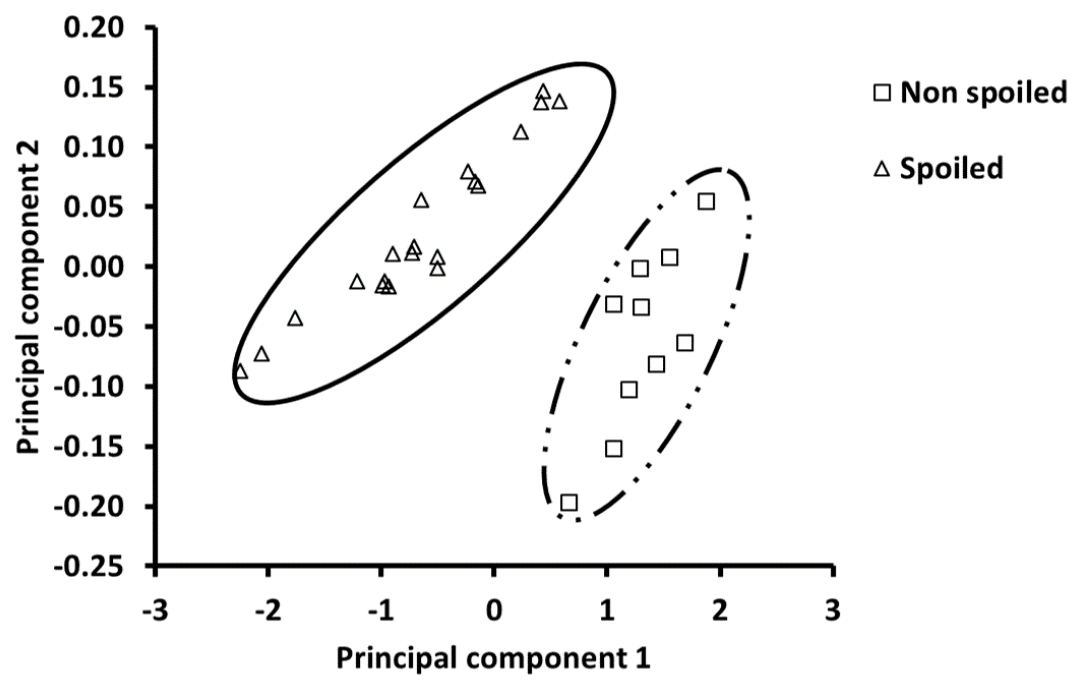

Figure 11: Quality classes of fresh pasteurized milk stored at $25^{\circ} \mathrm{C}$ as a function of time (2.3 days). 
and poor compared to two quality classes (i.e. non-spoiled and spoiled) of milk stored at $25{ }^{\circ} \mathrm{C}$ (Table 2 and Fig. 11). In general, the e-nose was a good classifier of the volatile profiles of pasteurized milk stored both at $4{ }^{\circ} \mathrm{C}$ and $25{ }^{\circ} \mathrm{C}$. Similarly, Vallejocordoba and Nakai (1994b) classified the quality of pasteurized milk into three classes, good, marginal, and poor using LDA.

\section{Conclusions}

The current study investigated the possibility of using the e-nose for shelf life determination of milk during storage (i.e. at $25{ }^{\circ} \mathrm{C}$ and $4{ }^{\circ} \mathrm{C}$ ). The electronic nose responses were correlated with the shift in the bacterial count of the tested milk samples. In addition, the e-nose was a good classifier of the aroma print of pasteurized milk at both room temperature and during refrigerated storage. Furthermore, milk quality was successfully classified using e-nose sensor responses and microbial data into three classes namely excellent, good, and poor. Early detection of milk spoilage is very important in reducing economic loss and the health risks of produced milk. Aroma-based detection of milk spoilage was very effective and could express both milk ageing and end of shelf life.

\section{Acknowledgements}

The authors would like to acknowledge the financial support from SQU-UAEU collaborative project CL/SQU-UAEU/2016/03.

\section{References}

Ali, Z., O'Hare, W. T. \& Theaker, B. J. (2003). Detection of bacterial contaminated milk by means of a quartz crystal microbalance based electronic nose $[29$ th International Vacuum Microbalance Techniques Conference, TEESSIDE UNIV, MIDDLESBROUGH, ENGLAND, SEP 05-07, 2001]. Journal of Thermal Analysis and Calorimetry, 71(1), 155-161. https : //doi.org/10.1023/A:1022274419166
Al-Qadiri, H. M., Lin, M., Al-Holy, M. A., Cavinato, A. G. \& Rasco, B. A. (2008). Monitoring quality loss of pasteurized skim milk using visible and short wavelength near-infrared spectroscopy and multivariate analysis. Journal of Dairy Science, 91(3), 950-958. https://doi.org/ $10.3168 /$ jds.2007-0618

Bondoc, I. (2007). Technology and quality control of milk and dairy products.

Capone, S., Epifani, M., Quaranta, F., Siciliano, P., Taurino, A. \& Vasanelli, L. (2001). Monitoring of rancidity of milk by means of an electronic nose and a dynamic PCA analysis. Sensors and Actuators BChemical, 78(1-3), 174-179. https://doi. org/10.1016/S0925-4005(01)00809-7

Di Natale, C., Olafsdottir, G., Einarsson, S., Martinelli, E., Paolesse, R. \& D'Amico, A. (2001). Comparison and integration of different electronic noses for freshness evaluation of cod-fish fillets [8th International Meeting on Chemical Sensors (IMCS-8), BASEL, SWITZERLAND, JUL 02-05, 2000]. Sensors and Actuators B-Chemical, r7y(1-2), 572-578.

Food and Drug Administration. (2017). Grade "A" Pasteurized Milk Ordinance. Available from: U. S. Department of Health and Human Services, Public Health Services., Washington. https:// www.fda. gov/media/114169/download

Groenen, P. \& Borg, I. (2015). Multidimensional scaling II.

Hammer, Ø., Harper, D. A. T., Ryan, P. D. et al. (2001). PAST: Paleontological statistics software package for education and data analysis. Palaeontologia electronica, $4(1), 9$.

Harding, F. (1995). Milk quality. Springer.

Kalit, M. T., Markovic, K., Kalit, S., Vahcic, N. \& Havranek, J. (2014). Application of electronic nose and electronic tongue in the dairy industry. Mljekarstvo, $64(4)$, 228-244.

Korel, F. \& Balaban, M. O. (2002). Microbial and sensory assessment of milk with an electronic nose. Journal of Food Science, 67(2), 758-764. https : / / doi .org / 10 . 1111/j.1365-2621.2002.tb10672.x 
Labreche, S., Bazzo, S., Cade, S. \& Chanie, E. (2005). Shelf life determination by electronic nose: Application to milk. Sensors and Actuators B-Chemical, 106(1), 199206. https://doi.org/10.1016/j.snb.2004. 06.027

Lucknakhul, N., Jindal, V. \& Jonglertjunya, W. (2014). Modeling keeping quality of pasteurized milk. Advanced Materials Research, 931, 1544-1548.

Magan, N., Pavlou, A. \& Chrysanthakis, I. (2001). Milk-sense: A volatile sensing system recognises spoilage bacteria and yeasts in milk. Sensors and Actuators BChemical, 72(1), 28-34. https://doi.org/ 10.1016/S0925-4005(00)00621-3

McAuley, C. M., Singh, T. K., Fernando HaroMaza, J., Williams, R. \& Buckow, R. (2016). Microbiological and physicochemical stability of raw, pasteurised or pulsed electric field-treated milk [International Nonthermal Processing Workshop on Sustainable Innovation Based on Science and Applied Research of Nonthermal Technologies, Athens, GREECE, NOV 12-13, 2015]. Innovative Food Science 83 Emerging Technologies, 38(B, SI), 365-373. https://doi.org/10. 1016/j.ifset.2016.09.030

Oliveros, C. C., Boggia, R., Casale, M., Armanino, C. \& Forina, M. (2005). Optimisation of a new headspace mass spectrometry instrument discrimination of different geographical origin olive oils. Journal of Chromatography A, 1076(12), 7-15. https://doi.org/10.1016/j. chroma.2005.04.020

Rahman, M. S., Al-Farsi, K., Al-Maskari, S. S. \& Al-Habsi, N. A. (2018). Stability of electronic nose (e-nose) as determined by considering date-pits heated at different temperatures. International Journal of Food Properties, 21(1), 849-856. https: / / doi .org / 10 . 1080/10942912 . 2018. 1463540

Rashid, A., Javed, I., Rasco, B., Sablani, S., Ayaz, M., Ali, M. A., Abdullah, M., Imran, M., Gondal, T. A., Afzal, M. I., Atif, M., Salehi, B., Rodrigues, C. E., SharifiRad, J. \& Martins, N. (2019). Measure- ment of off-flavoring volatile compounds and microbial load as a probable marker for keeping quality of pasteurized milk. Applied Sciences-basel, 9(5). https:// doi.org/10.3390/app9050959

RStudio. (2019). R: A language and environment for statistical computing. R Foundation for statistical Computing, Vienna, Austria. https://www.R-project.org/

Sadhu, S. P. (2018). Effect of cold chain interruptions on the shelf-life of fluid pasteurised skim milk at the consumer stage. Brazilian Journal of Food Technology, 21.

Slewa, E. K. \& Azhar, J. (2018). Use nanotechnology in capsulation omega-3 fatty acid to improve its thermal stability and use it to enrich pasteurized milk. Pak. J. Biotechnol. Vol, 15(1), 33-43.

Tohidi, M., Ghasemi-Varnamkhasti, M., Ghafarinia, V., Bonyadian, M. \& Mohtasebi, S. S. (2018). Development of a metal oxide semiconductor-based artificial nose as a fast, reliable and non-expensive analytical technique for aroma profiling of milk adulteration. International Dairy Journal, 77, 38-46. https://doi.org/10. 1016/j.idairyj.2017.09.003

Vallejocordoba, B. \& Nakai, S. (1994a). Keepingquality assessment of pasteurized milk by multivariate-analysis of dynamic headspace gas-chromatographic data .1. shelf-life prediction by principal component regression. Journal of Agricultural and Food Chemistry, 42(4), 989993. https : / / doi . org / 10 . 1021/ jf00040a029

Vallejocordoba, B. \& Nakai, S. (1994b). Keepingquality assessment of pasteurized milk by multivariate-analysis of dynamic headspace gas-chromatographic data .2. flavor classification by linear discriminant-analysis. Journal of $\mathrm{Ag}$ ricultural and Food Chemistry, 42(4), 994-999. https : / / doi .org / 10 . 1021/ jf00040a030

Vazquez-Landaverde, P. A., Velazquez, G., Torres, J. A. \& Qian, M. C. (2005). Quantitative determination of thermally derived off-flavor compounds in milk us- 
\begin{tabular}{l|l} 
Characterizing pasteurized milk by e-nose & 397
\end{tabular}

ing solid-phase microextraction and gas chromatography. Journal of Dairy Science, 88(11), 3764-3772. https:// doi. org/10.3168/jds.S0022-0302(05)73062-9

Walstra, P., Walstra, P., Wouters, J. T. M. \& Geurts, T. J. (2005). Dairy science and technology. CRC press.

Wehr, H. M., Frank, J. F., Association, A. P. H. et al. (2004). Standard methods for the examination of dairy products. American Public Health Association Washington, DC.

Ziyaina, M., Govindan, B. N., Rasco, B., Coffey, T. \& Sablani, S. S. (2018). Monitoring shelf life of pasteurized whole milk under refrigerated storage conditions: Predictive models for quality loss. Journal of Food Science, 83(2), 409-418. https: //doi.org/10.1111/1750-3841.13981

Ziyaina, M., Rasco, B., Coffey, T., Unlu, G. \& Sablani, S. S. (2019). Colorimetric detection of volatile organic compounds for shelf-life monitoring of milk. Food Control, 100, 220-226. https://doi.org/10. 1016/j.foodcont.2019.01.018 